\title{
Mandatory of Covid-19 Vaccination Requirements for Health Vitality on Prospective Hajj Pilgrims: An Innovation of Interactive Video and E-Poster
}

Norazlinda Hj Mohammad, Norena Abdul Karim Zamri, Liza Marziana Mohammad, Aidah Alias and Harniyati Hussin

To Link this Article: http://dx.doi.org/10.6007/IJARBSS/v11-i7/10333

DOI:10.6007/IJARBSS/v11-i7/10333

Received: 24 May 2021, Revised: 27 June 2021, Accepted: 18 July 2021

Published Online: 29 July 2021

In-Text Citation: (Mohammad et al., 2021)

To Cite this Article: Mohammad, N. H., Zamri, N. A. K., Mohammad, L. M., Alias, A., \& Hussin, H. (2021). Mandatory of Covid-19 Vaccination Requirements for Health Vitality on Prospective Hajj Pilgrims: An Innovation of Interactive Video and E-Poster. International Journal of Academic Research in Business and Social Sciences, 11(7), 1449-1457.

Copyright: (c) 2021 The Author(s)

Published by Human Resource Management Academic Research Society (www.hrmars.com) This article is published under the Creative Commons Attribution (CC BY 4.0) license. Anyone may reproduce, distribute, translate and create derivative works of this article (for both commercial and non-commercial purposes), subject to full attribution to the original publication and authors. The full terms of this license may be seen at: http://creativecommons.org/licences/by/4.0/legalcode

Vol. 11, No. 7, 2021, Pg. 1449 - 1457

Full Terms \& Conditions of access and use can be found at http://hrmars.com/index.php/pages/detail/publication-ethics 


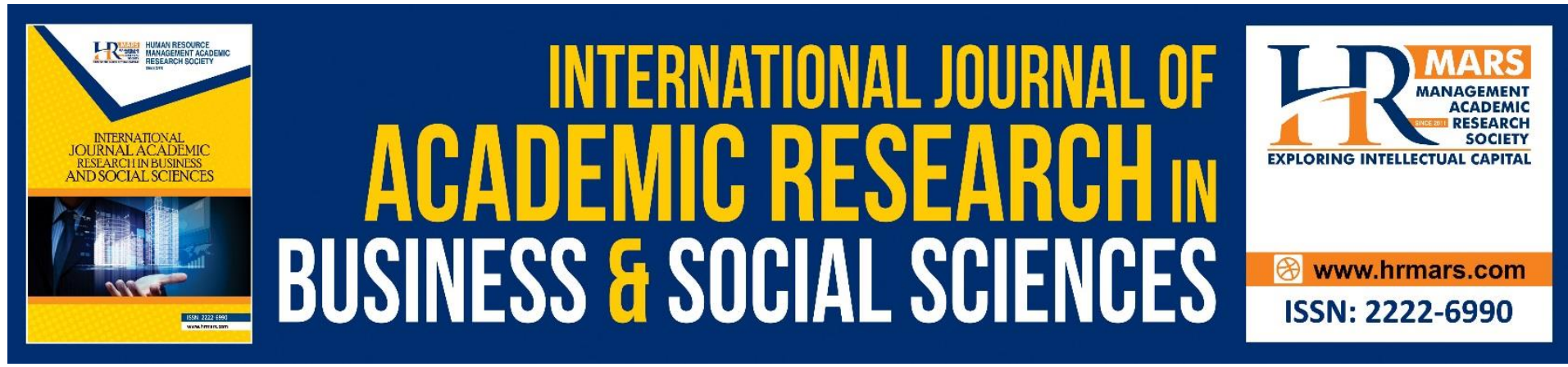

\title{
Mandatory of Covid-19 Vaccination Requirements for Health Vitality on Prospective Hajj Pilgrims: An Innovation of Interactive Video and E-Poster
}

\author{
Norazlinda Hj Mohammad ${ }^{1}$, Norena Abdul Karim Zamri ${ }^{1}$, Liza \\ Marziana Mohammad ${ }^{2}$, Aidah Alias ${ }^{2}$ and Harniyati Hussin ${ }^{3}$
}

Faculty of Communication \& Media Studies, Universiti Teknologi MARA Melaka, Malaysia ${ }^{1}$, Faculty of Art \& Design, Universiti Teknologi MARA Melaka, Malaysia², Faculty of Business Management, Universiti Teknologi MARA Melaka, Malaysia ${ }^{3}$

Email: linda333@uitm.edu.my

\begin{abstract}
As the world grapples with Covid-19 challenges, excellent health is critical since it aids in the pilgrimage process. This study seeks to identify the effective medium of communication in delivering information on health awareness and guidance for the pilgrims before they departed. The methodology used for this study is quantitative method by disseminating 120 questionnaires to Muslims. A total of 106 respondents participated by using snowball sampling. Data had been gathered and analyzed using IBM SPSS statistic software version 20.0 software database tool. The major findings show that the interactive video and e-poster play effective roles in highlighting the importance of taking Covid-19 vaccination. It also serves an effective communication medium in providing information on health awareness and guidance for pilgrims. The study suggests providing better health care services for Hajj pilgrims and increases the level of awareness, knowledge and responsibility among the pilgrims on the importance of health vitality in not only facing the pandemic but also overcoming the health problems as stipulated by the pilgrimage board. Further research is recommended to do expert evaluations on our Interactive Video and E-poster to evaluate the effectiveness of stressing the mandatory of taking Covid-19 vaccination before the pilgrimage. Keywords: Awareness, Covid-19 Vaccination, Health Vitality and Pilgrims, Consciousness
\end{abstract}

\section{Introduction}

Health education can be explained as a process by which individuals or groups learn to behave in a manner conducive to the promotion, maintenance, or restoration of health (Park, 2007). Communication in relation to health education involves various modes, e.g. lectures, discussions, symposia, posters, public address, and radio and television messages. Each mode has its own merits, drawbacks and scope of effectiveness. The effectiveness of the intervention depends on its suitability to the target audience in their specific settings and taking into consideration their backgrounds. At the same time, effective health education focused on prevention and control of respiratory tract infections during the Hajj pilgrimage 
depends on training, awareness, and compliance by Hajj pilgrims and healthcare workers involved

In 2007, an initiative called Health Education Ambassadors (HEA) was commissioned to provide health education for pilgrims upon their arrival during Hajj. The HEA are mandated with two cardinal objectives of providing effective health education for pilgrims in their mother tongue at their dormitories in the holy places and encourage medical students to actively take a health education role during the Hajj (Turkestani, 2013).

There are various kinds of media that exist today encompassing the printed media like the newspapers and magazines; the electronic media like the internet; social media like Facebook and Twitter; and online applications like WhatsApp, We Chat and Telegram and an abundance of mushroomed media platforms (Samad, 2014). Laranjo et al (2015) discovered that social media brought greater benefits in promoting positive health awareness. It saves cost, easy to access, and reaches people without any boundaries. Thus, an effective medium of communication that consists of both traditional and new media has to counter back and mitigate the rapid cases of deadly virus of Covid-19. Health consciousness on Covid-19 vaccination and knowledge on preventive measures must be addressed widely in newspapers, radio, television, posters, and pamphlets. Realising that technologies are evolving drastically as some travel agencies that handled pilgrimage had improvised their medium of communication to modern technologies in disseminating the messages towards their audiences Huebsch et al stated that social media networks enable health practitioners to have a direct contact with their clients.

The health communication campaign delivered in the traditional and new media platforms enforced by the Ministry of Health Malaysia (KKM) and National Security Council (MKN) on pandemic brings huge benefits to the public awareness in cultivating positive attitudes and behaviors change that may curb the spread of the Covid-19 by taking precautions adhering to cleanliness, wearing mask properly, sanitation and social distancing. There is no doubt that providing health education to pilgrims on non-communicable and infectious diseases (including the preventative measures and modes of infection transmission) is of great interest for the Hajj and health authorities in Saudi Arabia (Ahmed et. al., 2006). It is also critical for global public health and disease control, which is considered good practice to minimize the risks and improve compliance with preventative control measures (Shafi et. al., 2016).

This study presents the importance of taking Covid-19 vaccination to fulfill the mandatory requirements as a health preventive measure and highlights further the medium of communication that helps to deliver the information on health awareness and guidance for the pilgrims effectively as an advanced preparation before they departed to Mecca.

\section{Vaccination and Health Vitality on Pilgrims}

Realising that the Covid-19 had brought tremendous global impact to various sectors of political, social, health, economic, travel industries and ritual mass gatherings. Covid-19 vaccination programmes, health interventions through robust media were done extensively in creating public health awareness so as to stop the outbreak and fatal infections. It takes from the co-operation and co-ordination from health professional expert and development of clinicians; formation of health care systems, support groups; fund provision for health institutions in helping to curb and mitigate the spread of diseases. Yezli et al suggested that it is imperative for every prospective hajj pilgrims to take vaccination as a precaution against bacterial infections and diseases. Even before the COVID-19 pandemic, the Saudi Ministry of Health provides Hajj and Umrah requirements each year, with a focus on needed vaccines, 
together with important control measures for the safety of the individuals and prevention of infectious disease outbreaks. These recommendations are revised on an annual basis to reflect changes in the epidemiology of major infectious illnesses (Al-Tawfiq et. al., 2017)

For over 1400 years, the mass gathering during hajj has been linked to the spread of infectious illnesses, notably respiratory infections (Haworth et. al., 2013). Viral respiratory infections are a significant public health burden, causing severe illness, particularly in vulnerable populations. Every year, influenza-associated lower respiratory tract disease causes around 54 million infections, eight million episodes of severe illness, and 145,000 fatalities across all age groups (Troeger et. al., 2019). International travel is becoming more frequent and quicker, which increases the spread of respiratory illnesses, particularly in large crowds such as the Hajj pilgrimage in Mecca. (Memish et. al., 2019).

Respiratory infections account for $74 \%$ of all medical issues reported throughout the hajj seasons. Pneumonia is the leading cause of hospitalisation, accounting for $39 \%$ of all admissions. According to a recent study of Malaysian hajj pilgrims, $90 \%$ of them had at least one respiratory disease (Ahmed et. al., 2006). Other study showed that Malaysian pilgrims exhibited lower colonization rates among influenza-vaccinated pilgrims when compared with unvaccinated pilgrims though the rates were not statistically significant (Hashim et. al., 2016). This shows that such religious and other mass gatherings can increase the transmission of respiratory viruses by up to eight times (Memish et, al, 2019). The current coronavirus disease 2019 (COVID-19) epidemic exemplifies how travel hastens the transmission of respiratory viral illness.

\section{Methodology}

This study employed quantitative method by disseminating 120 questionnaires. A total of 106 respondents participated by using snowball sampling. Two versions of the semistructured quantitative survey instrument, one in English and the other is in Bahasa Malaysia, were used. The survey instrument was pretested and fine-tuned to address any issues arising from translations and suggestions made by the local population. Respondent's answers derived then translated as required into English, transcribed, coded and analyzed using IBM SPSS Statistic software version 20.0.

\section{Results \& Data Analysis}

A total of 120 respondents had participated in the survey, however, there are only 106 of them completed the survey questionnaires and the result shows 88.3 percent $(n=106)$ response rate were collected through this study. The data collected were entered into a Google Form and an Excel spreadsheet. The statistical analysis was performed using IBM SPSS Statistic software version 20.0. The detail of respondents' demographic as presented in Table 1. According to the table, there are somewhat more female responses (63\%) than male respondents (39\%) in terms of gender. Besides, most of the respondents were aged between 20 to 30 years old made up the majority of 70 of them (66\%), and followed by respondents aged between 31 to 40 (15 respondents $=14 \%$ ) and 41 to 50 years old ( 14 respondents = $13 \%)$. With respect to their level of education, $50.9 \%$ of total respondents hold their STPM or Diploma Certificate, and 2 respondents are holding their Ph.D., while the remaining shows Degree $=15$, Master $=22$, and Certificate $=1$, respectively. 
Table 1: Profile of Respondents

\begin{tabular}{|c|c|c|}
\hline Item & & Frequency (\%) \\
\hline \multirow[t]{2}{*}{ Gender } & Male & $39(37)$ \\
\hline & Female & $67(63)$ \\
\hline \multirow[t]{6}{*}{ Age } & $20-30$ & $70(66)$ \\
\hline & $31-40$ & $15(14)$ \\
\hline & $41-50$ & $14(13)$ \\
\hline & $51-60$ & $5(5)$ \\
\hline & $61-70$ & $2(2)$ \\
\hline & 71 and above & 0 \\
\hline \multirow[t]{7}{*}{ Occupation } & Private & $6(6)$ \\
\hline & Government & $24(23)$ \\
\hline & GLC & $3(2)$ \\
\hline & Self-employ & $6(6)$ \\
\hline & Pensioner & 0 \\
\hline & Student & $62(59)$ \\
\hline & Unemployed & $5(4)$ \\
\hline \multirow[t]{7}{*}{ Education Level } & PMR & 0 \\
\hline & SPM & $12(1.9)$ \\
\hline & STPM / Diploma & $54(50.9)$ \\
\hline & Degree & $15(14.2)$ \\
\hline & Master & $22(20.8)$ \\
\hline & Ph.D. & $2(1.9)$ \\
\hline & Certificate & $1(0.9)$ \\
\hline \multirow[t]{2}{*}{ Have performed Hajj or Umrah } & Yes & $44(42)$ \\
\hline & No & $62(58)$ \\
\hline \multirow{6}{*}{$\begin{array}{l}\text { Frequency of performing Hajj } \\
\text { or Umrah }\end{array}$} & 0 (never) & $62(58)$ \\
\hline & 1 & $27(26)$ \\
\hline & 2 & $8(8)$ \\
\hline & 3 & $4(3)$ \\
\hline & 4 & $1(1)$ \\
\hline & More than 5 times & $4(4)$ \\
\hline \multirow{2}{*}{$\begin{array}{l}\text { Have you ever used Utas } \\
\text { Travel services? }\end{array}$} & Yes & $10(10)$ \\
\hline & No & $96(90)$ \\
\hline \multirow{2}{*}{$\begin{array}{l}\text { Have you ever used Tabung } \\
\text { Haji Travel services? }\end{array}$} & Yes & $35(33)$ \\
\hline & No & $71(67)$ \\
\hline \multirow{2}{*}{$\begin{array}{l}\text { Awareness of the importance } \\
\text { of health care }\end{array}$} & Yes & $94(89)$ \\
\hline & No & $12(11)$ \\
\hline
\end{tabular}

Moreover, there are also five questions included in the demographic section that relate to the respondents' personal experiences on performing Hajj or Umrah using travel agent services. The data shows the majority of the respondents $(62 \%)$ have never had the opportunity to perform Hajj or Umrah yet. However, $42 \%$ of the respondents (44 of them) 
had performed Hajj and Umrah. Among these 44 respondents, there are 4 respondents who had the opportunity to performed Hajj or Umrah more than five times, while a majority of them had only once or twice.

This study did extend the survey pertaining on the awareness of the importance of taking care of their health while performing Hajj or Umrah. The results show 89\% (a total of 94 respondents) of them are aware, while $11 \%$ of respondents are still unaware on the importance of taking good care of their health. Due to this reason, therefore, several questions were posed to inquire about the importance of obtaining health information among pilgrims for Hajj and Umrah.

The study then expanded the research to look at the need on obtaining health information through interactive media platforms. As illustrated in Table 2.0, there were four questions that were posed to the respondents. Most respondents agreed that health screening and care information needs to use an interactive media platform to convey the information. $63.2 \%$ of total respondents agreed and strongly agree that the authority needs to utilize the use of social media platforms, while $69.8 \%$ agreed to use video or other interactive media. Furthermore, when the respondents were asked about the importance of acquiring information in the form of visuals or infographics, $61.3 \%$ of the total respondents stated they agree and strongly agree.

Table 2.0 Health Information Questions

\begin{tabular}{|l|l|l|l|l|l|}
\hline & $\begin{array}{l}\text { Strongly } \\
\text { Disagree }\end{array}$ & Disagree & Neutral & Agree & $\begin{array}{c}\text { Strongly } \\
\text { Agree }\end{array}$ \\
\hline $\begin{array}{l}\text { I know that health screening } \\
\text { information needs to be in the } \\
\text { form of pictures or } \\
\text { infographics to make its } \\
\text { delivery clearer. }\end{array}$ & $3.8 \%$ & $5.7 \%$ & $29.2 \%$ & $34.9 \%$ & $26.4 \%$ \\
\hline $\begin{array}{l}\text { I know that health care } \\
\text { information needs to be } \\
\text { disseminated through social } \\
\text { media }\end{array}$ & $3.8 \%$ & $11.3 \%$ & $21.7 \%$ & $26.4 \%$ & $36.8 \%$ \\
\hline $\begin{array}{l}\text { I know that the travel agency } \\
\text { or Lembaga Tabung Haji needs } \\
\text { to convey information through } \\
\text { interactive media applications } \\
\text { so that it can be uploaded by } \\
\text { pilgrims and umrah wherever } \\
\text { they are. }\end{array}$ & $0.9 \%$ & $3.8 \%$ & $22.6 \%$ & $31.1 \%$ & $41.5 \%$ \\
\hline $\begin{array}{l}\text { I know that information on } \\
\text { health screenings needs to be } \\
\text { conveyed } \\
\text { video/interactive media. }\end{array}$ & $0 \%$ & $6.6 \%$ & $23.6 \%$ & $34.9 \%$ & $34.9 \%$ \\
\hline
\end{tabular}

The respondents were also provided sample of 3 minutes infographic video related to Hajj and Umrah health information, which included numerous areas of health care such as procedures, guidelines, emergency actions, the contact number of the person in charge, and among other things. Table 3.0 indicates the result of their responses towards the video, and 
several questions were asked pertaining to that area. As clearly can be seen on the result, majority of the respondents agreed or strongly agreed that the infographic video had provided clear information on health screening to Hajj and Umrah pilgrims and $84 \%$ of them understand the video content. Another question was asked on the respondents so as to get confirmation or response on the improvement in the process of providing information to pilgrims on preparing their journey for hajj and umrah through the development and enhancement of video and interactive posters. Astoundingly, the result shows $83.1 \%$ of total respondents agreed and strongly agrees with the development of interactive video and posters as it helps deliver effectively and guides them in obtaining any information regarding on health care information before their pilgrimage.

Table 3.0 Health Information Questions

\begin{tabular}{|l|c|c|c|c|c|}
\hline & $\begin{array}{c}\text { Strongly } \\
\text { Disagree }\end{array}$ & Disagree & Neutral & Agree & $\begin{array}{c}\text { Strongly } \\
\text { Agree }\end{array}$ \\
\hline $\begin{array}{l}\text { Does this video provide clear } \\
\text { information on health } \\
\text { screening information to Hajj } \\
\text { and Umrah pilgrims? }\end{array}$ & $0 \%$ & $0 \%$ & $25.5 \%$ & $35.8 \%$ & $38.7 \%$ \\
\hline $\begin{array}{l}\text { Does this video provide easy- } \\
\text { to-understand information? }\end{array}$ & $0 \%$ & $0 \%$ & $16 \%$ & $45.3 \%$ & $38.7 \%$ \\
\hline $\begin{array}{l}\text { Will the production of this } \\
\text { interactive video and poster } \\
\text { can provide an improvement } \\
\text { in channelling information on } \\
\text { health check-ups to pilgrims } \\
\text { for Hajj and Umrah? }\end{array}$ & $0 \%$ & $0 \%$ & $17 \%$ & $42.5 \%$ & $40.6 \%$ \\
\hline
\end{tabular}

\section{Conclusion and Recommendation}

The spread of the Covid 19 viruses has resulted in a temporary cessation of life activities of the world. The effects of this outbreak had affected our way of life tremendously in various sectors of political, social, health, job flows, economic, travel industries, and ritual mass gatherings. Through these circumstances, this study gazed for a positive perspective with the spread of Covid 19. The researcher had taken the opportunity to develop innovation through the medium of interactive video and e-poster. This study highlights the importance of taking the Covid-19 vaccination, spreading awareness of taking vaccination, and identifying the effective medium of communication on delivering the information on health awareness and also guidance for the hajj pilgrims before they departed for the holy land. Health is wealth and upon realizing it being in a good state of health, fit, and getting sufficient information are very important on performing hajj and at the same time able to control the spread of Covid 19. This study had discovered the effective medium in not only delivering information and knowledge on health awareness but also serve beneficial guidance for the hajj pilgrims before they departed for the holy land.

In conclusion, the effective medium in delivering the information and guidance during the Covid 19 is interactive video and e-poster. The essential element in the interactive video and e-poster conveys the vital information needs of health screening and care. The interesting and simple visuals or info graphics also play a crucial role in making the user understand the message. Furthermore, the most essential elements in developing interactive videos and 
posters are that the content must help deliver effectively and guide the pilgrims in obtaining information regarding health care information before their pilgrimage. This interactive video and e-poster also provide information on highlighting the importance of taking the Covid-19 vaccination. Thus, interactive video and e-poster can save cost, easy to access, and reaches people without any boundaries

Therefore, this study recommends that innovation on medium such as interactive video and e-poster play a vital role in delivering the information on health screening. Thus, at the same time it also does increasing the awareness among the pilgrims to take the Covid-19 vaccine. In addition, it is an effective communication medium in providing information on health awareness and guidance for pilgrims. The significance of this research paper is that it will optimistically provide better healthcare amenities for hajj pilgrims. Furthermore, the interactive video and e-poster not only can help increasing awareness, knowledge, and responsibility among pilgrims on the importance of attaining health quality and survival in facing the pandemic but also overcome health problems as prescribed by the hajj board. For further research, this study recommends for further investigation on the expert evaluation in the effectiveness of the interactive video and e-poster for better improvement towards greater health vitality and user needs.

\section{Acknowledgement}

This research was supported by Entiti Kecemerlangan (EK) Media and Visual Communication (EK Tier 5) Universiti Teknologi MARA Malacca branch and UTAS Travel Agency Alor Gajah. The supporters had no role in study design, data collection and analysis, decision to publish, or preparation of the manuscript.

\section{References}

Ahmed, Q. A., Arabi, Y. M., \& Memish, Z. A. (2006). Health risks at the Hajj. The Lancet, 367(9515), 1008-1015.

Al-Tawfiq, J. A., Gautret, P., \& Memish, Z. A. (2017). Expected immunizations and health protection for Hajj and Umrah 2018-An overview. Travel medicine and infectious disease, 19, 2-7.

Collinson, S., Khan, K., \& Heffernan, J. M.. (2015). The Effects of Media Reports on Disease Spread and Important Public Health Measurements. PLOS ONE, 10(11), e0141423. PLOS ONE. Retrieved from https://dx.doi.org/10.1371/journal.pone.0141423.

Ellis, L. A., Collin, P., Davenport, T. A., Hurley, P. J., Burns, J. M., \& Hickie, I. B. (2012). Young Men, Mental Health, and Technology: Implications for Service Design and Delivery in the Digital Age. Journal of Medical Internet Research, 14(6), e160. Journal of Medical Internet Research.. Retrieved from https://dx.doi.org/10.2196/jmir.2291.

Giustini, D. M., Ali, S. M., Fraser, M., \& Boulos, M. N. K. (2018). Effective uses of social media in public health and medicine: a systematic review of systematic reviews. Online Journal of Public Health Informatics, 10(2). Online Journal of Public Health Informatics.. Retrieved from https://dx.doi.org/10.5210/ojphi.v10i2.8270.

Hashim, S., Ayub, Z. N., Mohamed, Z., Hasan, H., Harun, A., Ismail, N., ... \& Aziz, A. A. (2016). The prevalence and preventive measures of the respiratory illness among Malaysian pilgrims in 2013 Hajj season. Journal of travel medicine, 23(2).

Haworth, E., Barasheed, O., Memish, Z. A., Rashid, H., \& Booy, R. (2013). Prevention of influenza at Hajj: applications for mass gatherings. Journal of the Royal Society of Medicine, 106(6), 215-223. 
Huesch, M. D., Galstyan, A., Ong, M. K., \& Doctor, J. N. (2016). Using Social Media, Online Social Networks, and Internet Search as Platforms for Public Health Interventions: A Pilot Study. Health services research, 51 Suppl 2(Suppl 2), 1273-1290. https://doi.org/10.1111/1475-6773.12496.

Laranjo, L., Arguel, A., Neves, A. L., Gallagher, A. M., Kaplan, R., Mortimer, N., Mendes, G. A., et al.. (2015). The influence of social networking sites on health behavior change: a systematic review and meta-analysis. Journal of the American Medical Informatics Association, 22(1), 243-256. Journal of the American Medical Informatics Association.. Retrieved from https://dx.doi.org/10.1136/amiajnl-2014-002841.

Memish, Z. A., Steffen, R., White, P., Dar, O., Azhar, E. I., Sharma, A., \& Zumla, A. (2019). Mass gatherings medicine: public health issues arising from mass gathering religious and sporting events. The Lancet, 393(10185), 2073-2084.

Misra, A. K., Sharma, A., \& Shukla, J. B. (2015). Stability analysis and optimal control of an epidemic model with awareness programs by media. Bio Systems, 138, 53-62. https://doi.org/10.1016/j.biosystems.2015.11.002

Samad, N. R. A. (2014). Peranan media dalam melestarikan kasih sayang. Retrieved from http://eseminar.dbp.gov.my/wacanakeputeraansultan/kasihsayang.pdf.

Anwar, S. F. (2020). Jemaah Perlu periksa kesihatan sebelum ke tanah suci-TH. Retrieved from: https://www.bharian.com.my/berita/nasional/2019/03/538666/jemaah-perlu-periksakesihatan-sebelum-ke-tanah-suci-th

Turkestani, A., Balahmar, M., Ibrahem, A., Moqbel, E., \& Memish, Z. A. (2013). Using health educators to improve knowledge of healthy behaviour among Hajj 1432 (2011) pilgrims. East Mediterr Health J, 19(Suppl 2), S9-12.

Yezli, S., Gautret, P., Assiri, A. M., Gessner, B. D., \& Alotaibi, B. (2018). Prevention of meningococcal disease at mass gatherings: Lessons from the $\mathrm{Hajj}$ and Umrah. Vaccine, 36(31), 4603-4609. https://doi.org/10.1016/j.vaccine.2018.06.030 